УДК 342.951:001.895:001.38

DOI https://doi.org/10.51989/NUL.2021.6.13

\title{
ПУБЛІЧНО-ПРИВАТНЕ ПАРТНЕРСТВО У СФЕРІ НАУКОВО-ТЕХНОЛОГІЧНОГО РОЗВИТКУ
}

\section{Куркова Ксенія Миколаївна,}

доктор юридичних наук, старший дослідник, завідувач відділу науково-правових експертиз та законопроектних робіт Науково-дослідного інституту публічного права

Статтю присвячено дослідженню сутності, змісту та значенню публічно-приватного партнерства у сфері науково-технологічного розвитку. Проаналізовано співвідношення категорій «державно-приватне партнерство» й «публічно-приватне партнерство». Визначено, що використання терміна «публічно-приватне партнерство» щодо сфери застосування науковотехнологічного розвитку є раціональнішим, оскільки передбачає врахування ширшого кола інтересів, публічних і приватних, а також взаємодію всіх можливих учасників науково-технологічного розвитку.

Під публічно-приватним партнерством у сфері науково-технологічного розвитку запропоновано розуміти в широкому сенсі правову модель реалізації стратегії державної науковотехнологічної політики, засновану на оновлених концептуальних підходах щодо адміністративно-правового забезпечення науково-технологічного розвитку, що полягають у переході до мережевої моделі адміністрування на паритетних, демократичних, справедливих і коопераційних засадах із визначенням нової ролі та функцій держави в означених процесах на основі збалансованого публічно-приватного підходу, за якого держава виступає не як «регулятор відносин», а як «повноправний партнер»; у вузькому розумінні - сукупність юридично оформлених рівноправних відносин стратегічного, технологічно-інноваційного, фінансового, організаційно-кадрового, інформаційно-аналітичного, інституційного характеру між публічними та приватними партнерами, у яких сторони взаємодіють у процесі ухвалення рішень і координують спільні дії з метою спільного досягнення визначеного публічного інтересу, який формалізується в конкретних цілях науково-технологічного розвитку.

Визначено характерні ознаки публічно-приватного партнерства у сфері науково-технологічного розвитку. Виокремлено основні форми публічно-приватного партнерства у сфері науково-технологічного розвитку залежно від напрямів його реалізації, які доцільно впроваджувати в Україні з метою підвищення ефективності адміністративно-правового забезпечення науково-технологічного розвитку.

Ключові слова: публічно-приватне партнерство, державно-приватне партнерство, науково-технологічний розвиток, адміністративно-правове забезпечення, державна науковотехнологічна політика.

\section{Kurkova Kseniia. Public-private partnership in the field of scientific and technological development}

The article is devoted to the study of the essence, content and significance of public-private partnership in the field of scientific and technological development. The ratio of the categories "public-private partnership" and "state-private partnership" is analyzed. It is determined that the use of the term "public-private partnership" in the field of scientific and technological development is more rational, as it takes into account a wider range of interests, public and private, as well as the interaction of all possible participants in scientific and technological development.

It is proposed to understand public-private partnership in the field of scientific and technological development in a broad sense - a legal model for implementing the strategy of state scientific and technological policy, based on updated conceptual approaches to administrative and legal support of scientific and technological development. on a parity, democratic, fair and cooperative basis with the definition of a new role and functions of the state in these processes on the basis of a balanced public-private approach, in which the state acts not as a "regulator of relations" but as a "full partner"; and in a narrow sense - a set of legally formalized equal relations of strategic, technological-innovative, financial, organizational-personnel, information-analytical, institutional 
nature between public and private partners, in which the parties interact in the decision-making process and coordinate joint actions to achieve joint certain public interest, which is formalized for specific purposes of scientific and technological development.

The characteristic features of public-private partnership in the field of scientific and technological development are determined. The main forms of public-private partnership in the field of scientific and technological development depending on the areas of its implementation, which should be implemented in Ukraine in order to increase the efficiency of administrative and legal support of scientific and technological development.

Key words: public-private partnership, state-private partnership, scientific and technological development, administrative and legal support, state scientific and technological policy.

Взаємодія інститутів держави, бізнесу та громадянського суспільства здійснюється шляхом застосування різних форм і методів, зокрема за допомогою державноприватного управління, яке поширене у світовій практиці й уважається більш результативним, ніж суто державне. Держава має владні повноваження визначати цілі й завдання розвитку, надавати дозвіл на здійснення діяльності в межах власної компетенції представникам приватного сектору, приймати необхідні нормативноправові акти тощо. Приватному управлінню властиві гнучкість, мобільність, швидкість прийняття рішень, здатність до запровадження інновацій. Більшість розвинутих країн поєднали найкращі риси державного й приватного управління, застосовуючи механізм державно-приватного партнерства $[1$, с. 140$]$.

Тема державно-приватного партнерства в інноваційній сфері та досліджень і розробок (R\&D) в Україні $\epsilon$ актуальною, бо основна частка наукових R\&D cконцентрована в державному секторі (академічної і вишівської науки), яка не пристосована для здійснення інноваційної діяльності, бо $€$ некомерційною сферою господарювання, а також не має необхідних фінансових та інфраструктурних ресурсів. При цьому в рамках регулювання означеної сфери відсутні будь-які мотиваційні важелі для залучення приватного сектору в інноваційне середовище. Тому держава, з одного боку, повинна зберегти й реалізувати свій науковий та інноваційний потенціал, а з іншого - забезпечити мотивацію та активізацію інноваційних відносин у приватній сфері. Ці завдання реалізуються в моделі державно-приватного партнерства [2, с. 184].

Потрібно констатувати, що в Україні сьогодні діє неефективна модель регулювання інноваційних відносин 3 пре- валюванням публічно-правових засобів регулювання науково-технологічного розвитку, зокрема інституційного фінансування й активним втручанням держави в означені процеси. Статистичні дані свідчать, що чинна модель не в змозі забезпечити сталий науково-технологічний розвиток, що зумовлює необхідність системних перетворень і зміни концептуальних підходів до адміністративно-правового забезпечення розвитку науки, технологій та інновацій і запровадження оновленої моделі інноваційного вектору науковотехнологічного розвитку з визначенням нової ролі держави в науково-технологічних процесах і збалансованого публічноприватного підходу.

Державно-приватне партнерство в науково-технічній та інноваційній сфері почало розвиватися відносно недавно. Тому залишаються недостатньо вивченими його особливості, моделі, організаційні форми й набутий практичний досвід, хоча окремі елементи державно-приватного партнерства в цій сфері привертали увагу ще класиків економічної науки. Наприклад, у вісімнадцятому сторіччі А. Сміт пропонував забезпечити передачу технологій, які належали державі, приватним особам, що, на його думку, дало 6 змогу більш ефективно використовувати капітал $\mathrm{i}$, як наслідок, підвищити податкові надходження [3, с. 98; 4].

I. Дубок відзначає, що в науковій літературі партнерство інститутів держави, бізнесу та громадянського суспільства визначають по-різному: трапляються такі поняття, як «публічно-приватне партнерство», «державно-приватне партнерство», «приватно-державне партнерство». Значна частина науковців ці поняття вживає як синоніми, що відповідають англомовному терміну «Public-Private Partnership», пояснюючи це особливістю перекладу 
іншомовних джерел. Разом із тим усе більше авторів розглядає «публічно-приватне партнерство» й «державно-приватне партнерство» як окремі взаємовиключні поняття, уживання яких пов'язане з роллю та функціями держави в суспільстві. Змістове використання цих понять залежить від моделі й культури державного управління [1, с. 141]. С. Кочеткова відмічає, що слово «public» перекладається як «держава», що, здавалося 6 , значно звужує суть поняття, яке прийшло до нас із Заходу. Однак «держава» (public) тут трактується ширше, ніж проста сукупність установ, що здійснюють владні функції. Воно виступає узагальненим суб'єктом публічної влади, що включає всі рівні управління - федеральний (національний), регіональний і муніципальний. Під «public» розуміється сукупність суспільних інститутів, які реалізують свої владні повноваження, а також відіграють часом неофіційну, неформальну, але важливу роль у розвитку суспільних процесів. у визначенні публічно-приватного партнерства держава стоїть на першому місці, так як $\epsilon$ ініціатором більшості проектів $[5$, c. $10 ; 6]$.

С. Грищенко вважає, що поняття «публічно-приватне партнерство» найбільш точно відтворює й сутність відносин, оскільки як публічний партнер у зарубіжний практиці часто $€$ не лише органи державної влади, а й органи місцевого самоврядування, потужні громадські організації та благодійні фонди $[1 ; 7$, с. 7]. В українській правовій реальності усталеним став термін «державно-приватне партнерство», що викликане скоріше за все традиційно великою роллю держави в суспільних відносинах. Повністю погоджуємося 3 вищенаведеною позицією С. Грищенко, а також із позицією О. Сімсон стосовного того, що використання словосполучення «публічно-приватне партнерство» не тільки відображає участь у партнерстві суб'єктів публічного та приватного права, а й свідчить про взаємодію інтересів - публічних і приватних. Із цієї точки зору вживання терміна «публічноприватне партнерство» $\epsilon$ коректнішим. Крім того, публічним партнером в означеній сфері $\epsilon$ не тільки держава, а й територіальна громада, а також державні та комунальні установи, підприємства, організації, об'єднання [8, с. 230]. Отже, використання терміна «публічно-приватне партнерство» стосовно сфери застосування науково-технологічного розвитку $\epsilon$ більш раціональним, адже передбачає урахування більш широкого кола інтересів - публічних і приватних, а також взаємодію всіх можливих учасників науковотехнологічного розвитку.

Варто відмітити, що чинний Закон України «Про державно-приватне партнерство» [9] (ст. 4 «Сфери застосування державно-приватного партнерства») від 1 липня 2010 року № 2404-VI не передбачає серед сфер застосування Закону наукові дослідження та розробки. Разом із тим у Концепції розвитку державноприватного партнерства в Україні на 2013-2018 роки, затвердженій Розпорядженням Кабінету Міністрів України від 14 серпня 2013 р. № 739-р, визначено, що пріоритетними сферами застосування державно-приватного партнерства $\epsilon$ виробнича інфраструктура й високотехнологічне виробництво (транспорт і зв'язок, транспортна інфраструктура, енергетичний сектор, машинобудування); наукова, науково-технічна, інноваційна та інформаційна сфери. На наш погляд, спеціальні норми щодо інструментів і механізмів реалізації публічно-приватного партнерства в науково-технологічній сфері, які, по суті, сьогодні відсутні, мають бути визначені на законодавчому рівні, а не підзаконному.

Найбільш загальне визначення дає Світовий банк: «Державно-приватне партнерство - це угоди між публічною і приватною сторонами з приводу виробництва й надання інфраструктурних послуг, які укладаються 3 метою залучення додаткових інвестицій і як засіб підвищення ефективності бюджетного фінансування» $[5$, c. $11 ; 10]$.

Комітет ОЕСР 3 науково-технологічної політики визначив державно-приватне партнерство в інноваційних процесах як «будь-які офіційні відносини або домовленості на фіксований/необмежений період часу між державними й приватними учасниками, у якому обидві сторони взаємодіють у процесі ухвалення рішення і співінвестують обмежені ресурси, такі як гроші, персонал, устаткування й інформацію для 
досягнення конкретних цілей у визначеній сфері науки, технологій та інновацій» $[11 ; 12]$. «Взаємовідносини сторін державно-приватного партнерства повинні бути зафіксовані в офіційних документах (договорах, програмах тощо), носити партнерський, тобто рівноправний характер» $[3$, с. $10 ; 13]$.

А. Лінк стверджує [14], що публічноприватне партнерство варто розглядати так: 1) відносини формальні й неформальні (тобто офіційні та неофіційні) між публічними й приватними учасниками R\&D процесів (до публічних він відносить федеральний уряд, уряд штатів і локальні органи, державні лабораторії, науково-дослідні інститути, державні університети, державні установи, організації та підприємства, а також об'єднання, а до приватного сектора - будь-які організаційно-правові форми, особливо спеціалізовані комерційні фірми); 2) інституціональне об'єднання державних і приватних фінансових, інфраструктурних і дослідних ресурсів, причому участь держави може бути як визначальною, так і навпаки [8, c. 228].

В. Варнавський визначає державноприватне партнерство як «юридично закріплену на певний термін форму взаємодії між державою і приватним сектором щодо об'єктів державної й муніципальної власності, а також послуг, що виконуються й надаються державними та муніципальними органами, установами й підприємствами, таку, що передбачає співфінансування та поділ ризиків» [15].

Д. Делмон під державно-приватним партнерством у найбільш широкому сенсі визначає будь-які контрактні або юридичні відносини між державними та приватними структурами з метою поліпшення й/або розширення інфраструктурних послуг, виключаючи контракти за державним замовленням (державні закупівлі). Термін «держава» в цьому випадку використовується для позначення певного рівня публічної влади, що відповідає за процеси реформування (національний, регіональний чи муніципальний рівні управління) $[16$, c. 2].

Ураховуючи наведені вище дефініції, у межах дослідження під публічно-приватним партнерством у сфері науково-техно- логічного розвитку пропонуємо розуміти в широкому розумінні правову модель реалізації стратегії державної науково-технологічної політики, засновану на оновлених концептуальних підходах до адміністративно-правового забезпечення науковотехнологічного розвитку, які полягають у переході до мережевої моделі адміністрування на паритетних, демократичних, справедливих і коопераційних засадах із визначенням нової ролі та функцій держави в означених процесах на основі збалансованого публічно-приватного підходу, за якого держава виступає не як «регулятор відносин», а як «повноправний партнер»; у вузькому розумінні - сукупність юридично оформлених рівноправних відносин стратегічного, технологічно-інноваційного, фінансового, організаційнокадрового, інформаційно-аналітичного, інституційного характеру між публічними та приватними партнерами, у яких сторони взаємодіють у процесі ухвалення рішень і координують дії з метою спільного досягнення визначеного публічного інтересу, який формалізується в конкретних цілях науково-технологічного розвитку.

Продовжуючи аналіз публічно-приватного партнерства у сфері науково-технологічного розвитку, варто окреслити характерні ознаки такого партнерства. Виходячи з наведеного вище визначення публічно-приватного партнерства у сфері науково-технологічного розвитку, можемо виділити такі його характерні ознаки: 1) суспільна необхідність партнерства задля досягнення цілей конкретно визначеного публічного інтересу, ефективність реалізації якого зумовлює доцільність формування партнерських зв'язків; 2) участь у партнерстві принаймні двох суб'єктів, один із яких - представник публічного, а інший - приватного сектору; 3) паритетність публічних і приватних партнерів як перед законом, так і за обсягом прав та обов'язків; 4) спільність, взаємоузгодженість і єдину спрямованість інтересів публічних і приватних партнерів задля досягнення спільної мети, конкретних цілей науково-технологічного розвитку й отримання взаємної вигоди; 5) об'єднання ресурсів (фінансово-економічних, матеріально-технічних, організаційно-кадрових, інформаційних тощо) 
публічних і приватних партнерів, а також спільне використання науково-технологічних результатів, справедливий спільний розподіл витрат і прибутків, можливих ризиків і відповідальності; 6) урегулювання партнерських відносин на договірній чи організаційно-інституційній основі, які паралельно $€$ основними правовими формами організації таких відносин.

Аналіз практики європейських країн свідчить, що публічно-приватне партнерство розглядається більшістю з них як пріоритетний інструмент реалізації інноваційної політики за такими напрямами: 1) стратегічне співробітництво у сферах критично важливих для держави (суспільства) соціальних інновацій і високих технологій; 2) забезпечення зв'язків між наукою й бізнесом і трансферу технологій у ринковий обіг; 3) розумна підтримка суб'єктів підприємництва, малих і середніх підприємств, приватних інвестицій у дослідження й інновації, за допомогою партнерського фінансування та розподілу ризиків між публічним і приватним партнерами; 4) кластероорієнтована політика [8, c. 227].

Як правило, державно-приватне партнерство у сфері наукових досліджень і розробок у країнах ЄC - це відкрита або напіввідкрита платформа для співробітництва науки, бізнесу і влади. Державноприватне партнерство забезпечує рамкові умови не тільки для спільного фінансування процесу трансферу технологій, а й для спільного використання наукових результатів, інформації, нових технологій, інтелектуальної власності тощо. Державно-приватні партнерства зазвичай використовуються для досягнення нових результатів досліджень та ідей, отриманих державними науковими установами, i їх просування на ринок для підтримки нових інноваційних компаній, включаючи створення стимулів для державних наукових установ створювати нові підприємства, для сприяння комерційної експлуатації нових продуктів державних наукових установ, інформаційних послуг тощо [17, с. 116-117].

У матеріалах Проекту ЄС «Удосконалення стратегій, політики та регулювання інновацій в Україні» зазначається, що на основі аналізу інноваційної політики
Австралії, Австрії, Франції й Нідерландів ОЕСР виділила чотири типи заходів, що використовуються в традиційній політиці у сфері інновацій: 1) політика державних закупівель, що має цільову орієнтацію; 2) державне виконання R\&D та політика трансферу технологій з державного сектору; 3) субсидіювання бізнесових R\&D за допомогою прямих і непрямих методів фінансування; 4) інфраструктурна допомога бізнесовим R\&D різними службами (кластероорієнтована політика) [2, с. 187].

А. Грибовський і В. Судариков зазначають про такі основні напрями програм державно-приватного партнерства: 1) стимулювання співпраці між науковим і промисловим секторами економіки; 2) підтримка високотехнологічних start-up і «spin-off» компаній; 3) сприяння трансферу технологій [18, с. 176].

Висновки. Отже, проведений аналіз дає змогу виокремити такі основні форми публічно-приватного партнерства у сфері науково-технологічного розвитку залежно від напрямів його реалізації, які доцільно впроваджувати в Україні з метою підвищення ефективності адміністративно-правового забезпечення науково-технологічного розвитку: 1) стратегічне партнерство (вироблення спільних стратегій і програм науково-технологічного розвитку, створення інноваційно-технологічних платформ); 2) науково-освітнє партнерство (створення неприбуткових науково-дослідних, освітніх організацій, які здійснюють оцінку ринкової конкурентоспроможності досліджень, надають освітні послуги, зокрема з підвищення кваліфікації, надають допомогу у сфері доконкурентних досліджень, при оформленні прав інтелектуальної власності, патентному пошуку, оподаткуванні, бухгалтерському обліку об'єктів інтелектуальної власності); 3) комерційно-виробниче партнерство (створення комерційних установ з метою трансферу технологій, комерціалізації результатів науково-технологічної діяльності, які зазвичай створюються на базі вищих навчальних закладів або науководослідних установ: центри трансферу технологій, центри комерціалізації інновацій, стартап-компанії інноваційно-технологічних центрів); 4) фінансово-економічне 
партнерство (створення венчурних фондів спільного публічно-приватного інвестування, запровадження програм публічноприватного фінансування, податкових програм підтримки); 5) інфраструктурне партнерство (створення інноваційних кластерів, полісів, наукових парків, бізнес-інкубаторів тощо).

\section{ЛITEPATУРA:}

1. Дубок I. Сутність та особливості державно-приватного партнерства. Збірник наукових праць Національної академії державного управління при Президентові України. 2014. Вип. 2. С. 139-149.

2. Інноваційна політика. Європейський досвід та рекомендації для України. Київ : Фенікс, 2011. Том 2 : Аналіз законодавства України у сфері досліджень, розробок та інноваційної діяльності та пропозиції щодо доповнень до законодавства. Проект ЄС «Вдосконалення стратегій, політики та регулювання інновацій в Україні». 350 с.

3. Чмир О., Шкворець Ю., Єгоров I. Державно-приватне партнерство у науково-технічній та інноваційній сфері: теоретичні засади та практичні проблеми впровадження в Україні. Наука та наукознавство. 2012. № 3. С. 98-109.

4. Смит А. Исследование о природе и причинах богатства народов. Москва : Эксмо, 2007. 960 c.

5. Кочеткова С. Государственно-частное партнёрство: учебное пособие. Москва : Издательский дом Академии естествознания, 2016. 174 с.

6. Румянцева А. Кластерная политика как стратегия регионального развития. Москва : Издательский дом МИСиС, 2013. 235 с.

7. Грищенко С. Підготовка та реалізація проектів публічно-приватного партнерства : практ. посіб. для органів місцев. влади та бізнесу. Київ : ФОП Москаленко О., 2011. 140 с.

8. Сімсон О. Державно-приватне партнерство в інноваційній сфері. Вісник Академії правових наук України. 2011. № 4. С. 222-230.

9. Про державно-приватне партнерство : Закон України від 1 липня 2010 року № 2404-VI. Відомості Верховної Ради України. 2010. № 40. Ст. 524.

10. Delmon J. Private Sector Investment in Infrastructure: Project Finance, PPP Projects and Risk. The World Bank and Kluwer Law International. 2009. P. 7.

11. OECD. Science, Technology and Industry Outlook. Paris, 2004. 234 p.

12. Сімсон О. Державно-приватне партнерство як пріоритетний механізм реалізації сучасної інноваційної політики України. Інноваційна політика та законодавство в Європейському Союзі та Україні: формування, досвід, напрямки наближення : матеріали Міжнар. симп. (Київ, 2-3 червня 2011 р.). С. 87-91.

13. Шелгунов А. Государственно-частное партнерство как форма взаимодействия государства, науки и бизнеса. Технологический прорыв России: стратегическое партнерство государства и бизнеса : материалы науч.-практ. конфер. (Москва, 7-10 февраля 2006 г.). URL: http:// www.vneshmarket.ru/content/document_r_68C7C2C7-D2A7-49A3-8275-5318784061D6.html.

14. Albert N. Link. Government as Enterpreneur. N.-Y. ; Oxford : University Press, 2009. 196 c.

15. Варнавский В. Управление государственно-частными партнерствами за рубежом. Вопросы государственного и муниципального управления. 2012. № 2. С. 134-147.

16. Делмон Д. Государственно-частное партнёрство в инфраструктуре практическое руководство для органов государственной власти. 2010. URL: http://www.fa.ru/org/chair/ gchp/Documents/biblio/Делмон\%20public_private_partner.pdf.

17. Інноваційна політика: Європейський досвід та рекомендації для України. Київ : Фенікс, 2011. Том 1 : Ключові особливості інноваційної політики в якості основи для розробки заходів сприяння інноваціям, що спрямовують Україну до заснованої на знаннях конкурентоспроможної економіки - порівняння ситуації в ЄС і Україні. Проект ЄС «Вдосконалення стратегій, політики, та регулювання інновацій в Україні». 214 с.

18. Грибовский А., Судариков А. Приоритетные направления государственно-частного партнерства в научно-технической и инновационной сферах (опыт зарубежных стран). Управление наукой и наукометрия. 2011. Вып. 10. С. 175-191. 